\title{
Zastupljenost trećoredske glagoljaške tradicije u nastavi hrvatskoga jezika
}

Rad prikazuje rezultate istraživanja zastupljenosti trećoredske glagoljaške tradicije u nastavnim priručnicima 19. i 20. stoljeća, točnije u čitankama književnosti i u udžbenicima jezika. Franjevci trećoreci glagoljaši zadužili su hrvatsku znanost i kulturu te su time zavrijedili da pojam trećoredske glagoljaške tradicije uđe u nastavničke priručnike. Tomu su, kao dokaz, navedene osobe i djela značajnih franjevaca trećoredaca glagoljaša. Budući da je glagoljaštvo neprekinuta tradicija franjevaca trećoredaca od 15. stoljeća do danas, gotovo je nemoguće govoriti o glagoljaštvu kao o hrvatskom kulturnom fenomenu, a ne spomenuti trećoredsku glagoljašku tradiciju. Stoga bi u budućim normativnim priručnicima hrvatskoga jezika bilo nužno jasnije odrediti pojmove glagoljaš i glagoljaštvo, navesti i pojasniti pojam franjevaca trećoredaca glagoljaša, navesti zaslužne franjevce trećorece glagoljaše u hrvatskoj kulturnoj povijesti i istaknuti ime fra Stjepana Belića, koji je prvi poznat službeni učitelj hrvatskoga jezika u hrvatskoj povijesti. Navedne činjenice upotpunit će, ovim istraživanjem dokazano, nepotpuno pojašnjene činjenice u nastavnim priručnicima hrvatskoga jezika o hrvatskom književnom srednjovjekovlju.

\section{Uvod}

Ovaj je rad podijeljen na tri dijela. Prvi dio donijet će rezultate istraživanja zastupljenosti trećoredske glagoljaške tradicije u nastavnim priručnicima 19. i 20. stoljeća, točnije u čitankama književnosti i u udžbenicima jezika. Drugi dio ukratko će pokazati čime su franjevci trećoreci glagoljaši zadužili hrvatsku znanost i kulturu te zašto je pojam trećoredske glagoljaške tradicije nužno uvesti u nastavničke priručnike i obraditi ga u nastavnom programu hrvatskoga jezika. Treći dio navest će konkretne prijedloge i imena franjevaca trećoredaca glagoljaša, koji bi trebali ući u nastavni plan i program hrvatskoga jezika.

\section{Zastupljenost trećoredske glagoljaške tradicije u nastavnim priručnicima hrvatskoga jezika 19. i 20. stoljeća}

Budući da tema rada nije povijest nastavničkih priručnika za hrvatski jezik, ne donosi se sustavno kronološki popis svih čitanki, odnosno udžbenika hrvatskoga jezika koji su se koristili tijekom povijesti hrvatskoga školstva. Takav bi pristup 
ovdje bio nepotreban jer je poznato da su čitanke u početku bile podijeljene $u$ cjeline tematski, a ne kronološki. ${ }^{1}$ Stoga ćemo ovdje prikazati čitanke i udžbenike koje u svom sadržaju imaju povijesni dio, dakle donose povijest hrvatske književnosti srednjega vijeka. Izabrano je nekoliko čitanki tiskanih za vrijeme AustroUgarske (1867. - 1918.). Zatim slijede čitanke tiskane za Kraljevine Srba, Hrvata i Slovenaca (1918. - 1929.), odnosno Kraljevine Jugoslavije (1929. - 1941.), a u sklopu koje je i vrijeme Banovine Hrvatske (1939. - 1941.). Slijede nastavnički priručnici tiskani tijekom i poslije Drugoga svjetskog rata, a na kraju su čitanke i udžbenici tiskani poslije Domovinskoga rata, sve do onih koji su i danas u upotrebi.

Rezultati istraživanja zastupljenosti trećoredske glagoljaške tradicije u nastavnim priručnicima 19. i 20. stoljeća, točnije u čitankama književnosti i u udžbenicima jezika, mogli bi se svrstati u nekoliko skupina. Prvu skupinu činili bi oni nastavni priručnici koji uopće ne spominju ni slavensku misiju Svete braće, a kamoli glagoljaštvo koje je čuvalo hrvatsku pisanu riječ u Hrvatskoj. ${ }^{2}$ Zatim slijede nastavnički priručnici u kojima se navodi tek pismo glagoljica, uvršteno u navođenje ostalih pisama (slikovno pismo, klinasto pismo, glagoljica, ćirilica, latinica). ${ }^{3}$ Ima velik broj priručnika za nastavu hrvatskoga jezika koji općenito navode misiju Svete braće i njezino značenje za slavenske narode. ${ }^{4}$ Nažalost, a to ovdje moramo spomenuti, bilo je i čitanki koje su otvoreno konstatirale da tekstovi crkvenih knjiga ne trebaju biti u čitankama jer ne pripadaju „ni narodnoj ni lijepoj knjizi“ te se stoga „crkveni jezik i njegova knjiga, premda su vrlo znamenita i skupocjena građa za izučavanje pravnih, državnih i prosvjetnih prilika našega naroda u ona vremena, opet ne mogu pribrojiti ni narodnoj ni lijepoj knjizi, pa joj zato ovdje nema mjesta“. Takva je čitanka za više razrede srednjih škola Franje Petračića, tiskana 1898. u Zagrebu. ${ }^{5}$ Isti pak Franjo Petračić 1880., dakle

Tako, primjerice, Čitanka za drugi razred glavnih i gradjanskih školah, tiskana 1846. u Trstu, donosi sljedeće cjeline: prvu posvećenu školskim zakonima za pučke škole u nasljednim zemljama austrijske carevine, drugu s ćudorednim tekstovima, treću s tekstovima prirodopisne tematike (O zemlji i ostalih nebeskih telesih, O carstvu živinah, Ptice, Ribe, O solih...), četvrtu s tekstovima o dužnostima prema vladaru, poglavarima i domovini, petu koja se odnosi na ćudoredne prosudbe, šestu s pravilima za pristojno vladanje te posljednju, sedmu, koja sadrži pravila za očuvanje zdravlja.

2 Tako je npr. u ZRINJAN I ZBUKOVIĆ-OŽBOLT 2009, obveznoj Čitanci za prvi razred trogodišnje strukovne škole.

3 Čitanka iz naše i strane književnosti za V. razred gimnazije (NIKOLIĆ, VEČERINA I DVORŽAK 1955: 10).

4 Takvih je dosta, a izdvojimo Čitanku za treći razred obćih pučkih škola iz 1889., koja u poglavlju Hrvati primaju sv. krst to donosi na sljedeći način: „A i sv. braća Ciril i Metud, slavenski apostoli, dodju u Hrvatsku, gdje su se odmorili i puk poučavali, kad su bili pošli u Rim noseći sa sobom kosti sv. Klimenta i prievod crkvenih knjiga. Oni prvi prevedoše sv. pismo na slavenski jezik“ (str. 86).

5 Franje Petračića Hrvatska čitanka za više razrede srednjih škola (MILER 1898: 6). 
18 godina prije upravo navedene čitanke, u Hrvatskoj čitanki za više gimnazije i nalike jim škole piše sljedeće: ,Jesu li Slaveni u obće, a Hrvati napose imali svoje osobito pismo, ne može se kazati. Prvo, koje se u njihovoj za sada poznatoj knjizi pojavljuje, jest g l a g o $1 \mathrm{~s} \mathrm{k} \mathrm{o} \mathrm{iliti} \mathrm{g} \mathrm{l} \mathrm{a} \mathrm{g} \mathrm{o} 1$ i c a. Ovo je pismo došlo k Hrvatom sa slavenskimi liturgijskimi knjigami, te se je upotrebljavalo i u javnom i u privatnom životu, a crkva ga je očuvala sve do najnovijih vremena". 6

Nama su ovdje najzanimljivije upravo čitanke koje spominju glagoljicu i slavenske liturgijske knjige, koje, dakle, govore o glagoljanju u Hrvata. Za početak navest ćemo čitanku iz 19. stoljeća, tiskanu 1879. u Beču, koja u poglavlju naslovljenom Sveti Ciril i Metod, slavjanski apoštoli navodi posebnost službe Božje u Hrvata jer su Hrvati, premda su obavljali službu Božju na staroslavenskom jeziku, ostali vjerni Katoličkoj crkvi, u kojoj se do pred kraj Drugoga vatikanskog koncila obavljala liturgija gotovo isključivo na latinskom jeziku: „Običaj, što su ga bila sv. bratja uvela najprije u Moravi, da su naime službu božju obavljali slavjanskim jezikom, bude malo kašnje uveden i kod hrvatskih Slavjanah; nu Hrvati su svedjer ostajali vêrni katoličkoj crkvi i njezinoj vidivoj glavi, premda se nikako nisu dali odvratiti od obavljanja službe božje u slavjanskom jeziku. Kašnje se je taj običaj medju njimi sve po malo gubio, ali sasvim nije prestao nikada ni do dana današnjega“" ${ }^{7}$

Većina čitanki slijedi naveden primjer te navodi slavenski jezik u liturgiji, odnosno u liturgijskim knjigama. Ono što pritom nedostaje jest nenavođenje činjenice tko su bili nositelji ili vršitelji te liturgije ,u slavjanskom jeziku“. Tako Tade Smičiklas u Hrvatskoj čitanci za III. razred gimnazijski iz 1880. piše: „Ćiril i Metod zovu se i jesu slavenski apoštoli, jer osim što je njihovo pismo (glagoljica), njihove knjige i jezik slavenski u liturgiji, utvrdjena je jošte što po njih, što po učenicih njihovih vjera Isusova kod većine naroda slavenskih"“. ${ }^{8}$ Isti tekst u potpunosti preuzima u svoju čitanku i ravnatelj zagrebačke Klasične gimnazije Mirko Divković. ${ }^{9}$

Ovdje se već spominje pojam ,učenicih“, koji, doduše prilično uopćeno, označava nositelje glagoljaške tradicije. Oni se u različitim čitankama različito imenuju, ali označavaju isto. Tako se koriste nazivi: ,narodno svećenstvo“"10, „učenici Ćirila

\footnotetext{
6 Hrvatska čitanka za više gimnazije i nalike jim škole (PETRAČIĆ 1880: 3, § 4. Pismo).

7 Četvrta čitanka za pučke učione. Sa zemljovidom Europe 1879: 192.

8 Hrvatska čitanka za III. razred gimnazijski (SMIČIKLAS 1880: 141, poglavlje Ćiril i Metod, od J. Tomića, str. 145).

9 U Hrvatskoj čitanci za III. razred gimnazijski, koju je po izdanju prof. T. Smičiklasa preradio Mirko Divković, i to u poglavlju Ćiril i Metod, od J. Tomića (DIVKOVIĆ 1889: 149).

10 Poglavlje Sveti Ćiril i Metodije u Čitanci za seoske opetovnice Ferde Ž. Milera donosi sljedeće: „Glavna im briga bijaše, da odgoje narodno svećenstvo, koje bi moglo nastaviti započeti posao. U tu svrhu sakupljahu učenike, poučavahu ih u narodnoj knjizi, u vjeri i liturgiji, te nastaviše prevod sv. pisma i liturgijskih knjiga“" (MILER 1891: 4).
} 
i Metoda“11, „,vjerni učenici“12, „niži svećenici“ ili „,niže svećenstvo“13. U čitanci za prvi razred ekonomskih škola iz 1997. Dragutina Rosandića kao nositelji glagoljske tradicije navedeni su „svjetovni svećenici“ (s tim da taj pojam, koji zvuči oksimoronski, nije pojašnjen), a crkveni redovi (benediktinci, franjevci i pavlini) spominju se kao nositelji književnoga života, odnosno književne tradicije. Tekstu je dodana sljedeća rečenica, koja kaže: „Među nositeljima književnoga života ističu se glagoljaši (popovi glagoljaši) čuvari crkvenostaro-hrvatskog jezika“" ${ }^{14}$ Točno je da su glagoljaši bili i „svjetovni svećenici“ i pripadnici navedenih crkvenih redova. Ali, u ovom obliku napisan, navedeni tekst zahtijeva ili dobro poznavanje glagoljaške tradicije ili bolje pojašnjenje spomenutih pojmova.

S ponosom ćemo u nekim čitankama pročitati da je kod nekih slavenskih naroda (Moravljani, Česi, Slovenci) nestalo traga slavenskoj riječi u službi Božjoj, a da su ,jedini Hrvati od svih slavenskih naroda rimskoga zakona održali do danas divnu baštinu svetih apostola Ćirila i Metodija“. ${ }^{15}$ Međutim, i ovdje nam nedostaje, a bilo bi hvale vrijedno, imenovanje nositelja i prenositelja te "divne baštine“. U Čitanci za IV. razred pučkih škola u Banovini Hrvatskoj, koju je priredio Sigismund Čajkovac, a surađivali su Vladimir Nazor, Stjepan Bosanac i Stjepan Ratković, govori se da je „protiv narodnoga bogosluženja“ bilo napadaja, „pa je ono s vremenom ukidano po hrvatskim krajevima“. I nastavlja se dalje: „Ali je Hrvatima ipak pošlo za rukom, te su sačuvali nakon tisuću godina tu svoju svetinju u biskupijama modruško-senjskoj, krčkoj i po nekim dalmatinskim krajevima gdje

${ }_{11}$ U Čitanci za niže pučke škole u gradovima (trgovištima), Srednji stupanj (III. godište), u ćirilicom tiskanom poglavlju pod naslovom Sv. Ćiril i Metod navedeno je sljedeće: „Kod Hrvata su kršćansku vjeru propovijedali učenici Ćirila i Metoda, te uveli i slavensku službu Božju, koja se u mnogim krajevima uzdržala sve do danas“ (1906: 143).

12 Tako u Mirka Divkovića Hrvatskoj čitanki za III. razred srednjih škola, koju je priredio PASARIĆ 1925, piše: „Poslije smrti Metodijeve njegovi se vjerni učenici doskora razbježaše na različne strane, tjerani i progonjeni, te postadoše rasadnikom novog procvjeta slavenske liturgije i slavenske crkvene literature" (str. 95).

13 U Pregledu književnosti s primjerima za VI. razred gimnazije iz 1956. najprije se navodi: „Nosioci hrvatske glagoljske književnosti bili su ponajviše samo niži svećenici, često bez dovoljne teološke i opće obrazovanosti“ (NIKOLIĆ 1956: 7), a potom: „Društveno je značenje glagoljaške književnosti u činjenici, što je to bila literatura nižega svećenstva i širih narodnih slojeva. Dok su se feudalci i više svećenstvo kulturno iživljavali na latinskom ili talijanskom jeziku, na glagoljici su pisana djela običnih ljudi“ (NIKOLIĆ 1956: 7-8).

U poglavlju Značajke hrvatske srednjovjekovne književnosti (ROSANDIĆ 1997: 194).

15 U poglavlju E. Proza. Pogled na hrvatsku prošlost. Iz djela „Povijest Hrvata“ (Vjekoslav Klaić) navodi se sljedeće: „U Moravana, Čeha, Slovenaca nestalo je traga slavenskoj riječi u službi Božjoj; jedini Hrvati od svih slavenskih naroda rimskoga zakona održali su do danas divnu baštinu svetih apostola Ćirila i Metodija! No koliko je borbe trebalo, koliko ustrajnosti i žilavosti kroz stoljeća, dok je napokon god. 1248. papa Inocentije IV. posvetio Hrvatima njihovo neosporivo pravo, da slave Boga u crkvi slavenskim jezikom (PASARIĆ I BOGDANOVIĆ 1924: 246). 
se još i sada glagolja. Svoju ljubav prema glagoljici nijesu Hrvati nikada prestali isticati sve do dana današnjega“. ${ }^{16}$

A glagoljali su i do dana današnjega glagoljaju glagoljaši. Tako dolazimo do nastavničkih priručnika za hrvatski jezik, koji izrijekom spominju glagoljaše i definiraju ih kao svećenike koji su vršili bogoslužje na narodnom jeziku. ${ }^{17}$ Osim što se glagoljaše spominje i definira, ističu se i njihove zasluge. Tako Ferdo Nikolić u svom Pregledu književnosti s primjerima za VI. razred gimnazije ističe nacionalnu zaslugu glagoljaša: „Nacionalne su zasluge glagoljaša što su oni u stoljećima teškoga političkoga i kulturnoga pritiska, koji se pomoću crkve sa strane talijanskoga elementa vršio u Istri, Dalmaciji i Hrvatskom primorju, postavili gotovo neprobojan zid svakome utjecanju, koje bi dovelo do odnarođivanja pomoću crkve i latinskoga jezika". ${ }^{18}$ Ovakve su se konstatacije lako uklapale u svijest nakon što je jugoslavenska strana na Pariškoj mirovnoj konferenciji 1946., prilikom rješavanja sporne granice s Italijom, isticala izrazito raširenu glagoljašku komponentu među istarskim svećenstvom, kao dokaz stoljetne kulturne prisutnosti hrvatskoga i slavenskoga identiteta na prostorima kulturnih i etničkih doticaja, kakva je npr. Istra. ${ }^{19}$ Pojam pak glagoljaška tradicija, blizak naslovu našega Simpozija, nalazimo u čitanci za prvi razred četverogodišnje srednje strukovne škole iz 2011., koja navodi da se jedino u ,hrvatskoj Katoličkoj crkvi, i to prije svega, u njenim biskupijama u Istri, Primorju i otocima“ razvila ,jedinstvena glagoljaška tradicija s posebnim oblikom glagoljičkih slova, tzv. uglatom glagoljicom, osobitom samo za Hrvatsku“. ${ }^{20}$

Iako se možda očekuje da ćemo iznošenje rezultata ovoga istraživanja završiti s nekom od čitanki 21. stoljeća, nažalost, nije tako. Čitanka tiskana u Zagrebu 1923., koja nosi naslov Čitanka iz književnih starina staroslovenskih, hrvatskih i srpskih za VII. i VIII. razred srednjih škola, a koju su sastavili Đuro Šurmin i Stjepan Bosanac, donosi sljedeće podatke. Najprije ponavlja zasluge popova glagoljaša (koje je već ranije istaknuo i Ferdo Nikolić), a zatim: „Da se očuvala glagolska služba do naših dana, treba zahvaliti najviše onoj žilavosti i ustrajnosti, što su je imali hrvatski neuki, ali narodni popovi glagolaši. Ova je ustrajnost uza slovensku službu spasila i narodni

\footnotetext{
16 U poglavlju Narodno bogosluženje s tekstom koji je tiskan ćirilicom (ČAJKOVEC 1940: 139).

17 „GLAGOLJAŠTVO U HRVATSKOJ. Prihvativši staroslavenski jezik kao jezik bogoslužja, Hrvati su u njega počeli unositi elemente narodnoga jezika. Takva se jezična promjena zove hrvatska redakcija staroslavenskoga jezika. Na njemu su glagoljicom bili napisani misali i brevijari (molitvenici), a svećenici koji su vršili bogoslužje na narodnom jeziku bili su glagoljaši. Najviše je glagoljaša bilo na otoku Krku (kolijevka glagoljice)“ (ŠPANJIĆ I DUJMOVIĆ-MARKUSI 2009: 160).

18 U poglavlju I. Srednjovjekovna književnost. I. Počeci slavenskih književnosti, Ćirilo i Metodije iz Pregleda književnosti s primjerima za VI. razred gimnazije (NIKOLIĆ 1956: 7).

19 TROGRLIĆ 2012: 487-493.

20 HORVATEK MODRIĆ I DR. 2011: 364.
} 
jezik i narodnu svijest, kojoj bez nje po svoj prilici ne bi bilo duga vijeka.“. ${ }^{21}$ Zatim navodi poteškoće na koje su glagoljaši nailazili: „Glagolaši su zbog svoje službe bili prezirani, zametavani pa im ni u kojem smjeru, ni u kojoj prilici nije niotkuda bilo pomoći. Ni gospoda ih nijesu osobito podupirala. Ali baš zbog toga, što su u ovakvim žestokim borbama samo od nevolje odvratili možda i najveće pogibije od svojega naroda, rad nam je njihov s tim znamenitiji i vredniji“".22 Na kraju se od znamenitih glagoljaša iz hrvatske prošlosti navode franjevci trećoreci glagoljaši, Šimun Klimantović i to kao Šimun Klemenović te Šimun Glavić. ${ }^{23}$

I ovdje ćemo stati s iznošenjem podataka, odnosno rezultata istraživanja. Pokušat ćemo se usmjeriti na upoznavanje trećoredske glagoljaške tradicije i donijet ćemo konkretne prijedloge za to koje bi osobe i koja djela trebali pronaći svoje mjesto u nastavničkim priručnicima.

\section{Glagoljica i staroslavenski jezik u franjevačkoj trećoredskoj zajednici}

Poznato je da su franjevci trećoreci glagoljaši „od svojih prvih početaka, arhivski dokumentiranih, od kraja 14. stoljeća (...) u Hrvatskoj (Dalmaciji) u privatnoj i službenoj crkvenoj komunikaciji“ “24, upotrebljavali hrvatski i hrvatski crkvenoslavenski jezik te pismo glagoljicu. Stoga su odmah u svojim počecima, još u srednjem vijeku ${ }^{25}$, prozvani glagoljašima - „religiosi illirici“ ${ }^{“ 26}$, „de littera

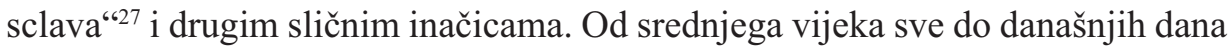
uglavnom nose taj časni naziv ,glagoljaši“.

Dva su bitna obilježja karizme franjevaca trećoredaca glagoljaša. To je pokornički duh po primjeru sv. Franje ${ }^{28}$, potvrđen u njihovu atributu „braće od pokore“ (fratres de penitentia), te glagoljsko pismo i staroslavenski jezik u svagdanjoj bogoslužnoj upotrebi. Oba su ih obilježja činila bliskima puku iz kojega su nikli i među kojim su radilii ${ }^{29}$, a ujedno ih je to i ujedinjavalo na cijelom hrvatskom na-

\footnotetext{
$21 \quad$ ŠURMIN I BOSANAC 1923: 22.

$22 \mathrm{Na}$ istome mjestu.

23 Isto: 25 .

24 RUNJE 2012: 158.

25 Isto: 16. „Dapače, možemo reći da je naziv „glagoljaši“(,glagolae“) prvi put upotrijebljen 1483. godine za franjevce trećoredce u Prvić Luci, u šibenskoj biskupiji“.

26 RUNJE 1990: 8.

27 Isto: 16; Isti 2012: 40.

28 Stoga su nazivani remete, odnosno eremiti della penitenza, heremitae S. Francisci, pauperes heremitae, heremita i slično, tj. pokornici (RUNJE 2012: 36).

29 „Stranac i nije mogao biti član zajednice koja je kao veliku vrijednost njegovala i čuvala hrvatski jezik“ (RUNJE 2012: 61), odnosno: „A pošto su oni bili ponajviše sinovi hrvatskoga puka, to su oni tim marljivije nastojali, da težake poučavaju u božjem nauku, obavljajući svedjer i crkvenu službu hrvatskomu puku omiljelim staroslavenskim jezikom kojim su se oni služili od svoga postanka“"(IVANČIĆ 1910: 28).
} 
rodnom prostoru. ${ }^{30}$ To će lijepo izraziti Stjepan Ivančić u uvodu svojih Povjestnih crta riječima: „Nije naših predja stalo bilo do velikih gradova i do znamenitih časti, već jedino da skromno sprovode život medju našim uvijek potištenim hrvatskim pukom, i da njemu uzmognu bilo kako, duhovno i tjelesno koristiti' ${ }^{\text {‘31 }}$ te nastavlja: „A pošto jedno od najvažnijih sredstava da se hrvatskomu puku duševno koristi jest obavljati mu i bogoslužje njegovim crkovnim jezikom, to su oni ća od svoga postanka u našim stranama rabili glagolicu, koja i danas sačinjava kano posebno obilježje dalmatinskih Trećoredaca“". ${ }^{32}$ Upravo jednostavnošću, a posebice propovijedanjem kršćanskoga nauka materinskim hrvatskim jezikom, stjecali su „ljubav i privrženost osobito nižega puka, koji ih je smatrao za svoje duhovne otce“. ${ }^{33}$ Posve je razumljivo da su vjernici rado sudjelovali u službi Božjoj, koja im je prilično razumljiva. Osim ljudi iz puka, velikodušnima prema njima pokazivali su se i „hrvatski imućnici, pa i sami upravitelji svjetovne vlasti““34, što se očitovalo u mnogim darovanim posjedima i sličnim darovnicama. Ipak, trećorece je uvijek krasila skromnost, što je vidljivo i u smještaju, odnosno u prostornoj poziciji, arhitekturi i inventaru njihovih samostana. Većinom su se osnivali na samotnim mjestima, ,jednostavni i neugledni; u njih ćelice tiesne i siromašne sa malašnim prozorima, kroz koje je jedva svjetlo provirivalo i zrak ulazio“. ${ }^{35}$ I njihova redovnička odjeća odaje tu skromnost i jednostavnost. Čak su je bili prisiljeni promijeniti. Naime, u početku su nosili odjeću sličnu opservantima, franjevcima Prvoga reda. Nakon što su opservanti podnijeli tužbu u Rim, zahtijevajući da franjevci trećoreci moraju promijeniti redovničko odijelo, kako puk ne bi dolazio u zabludu i poistovjećivao ih s njima, došlo je do sudske presude. Sudski proces održan je 10. studenoga 1466. u Rabu, pod predsjedanjem rapskoga biskupa Ivana Scaffe, delegata Svete Stolice. U presudi se točno opisuje kakvo treba biti odijelo trećoredaca: „Prema tom opisu ono se sastoji od četiri dijela: talara koji treba sezati 'usque super terram', pojasa od kože koji treba biti 'absque aliquo ornatu', kukuljice (kapuča) koja treba sezati preko pojasa; mantila koji treba odgovarati dužini talara“. ${ }^{36}$ Upravo je takvo izvorno trećoredsko odijelo prikazano na škrinji sv. Šimuna u Zadru, najvrednijem djelu srednjovjekovne zlatarske umjetnosti

\footnotetext{
$30 \quad$ Usp. RUNJE 2001: 147.

31 IVANČIĆ 1910: IV.

$32 \mathrm{Na}$ istome mjestu.

33 Isto: 30.

34 „Tako je knez Ivan Frankopan gospodar Krčkoga otoka, po izgledu svojih predja, liepo darovao i naše Trećoredce i po preporuci biskupa Nikole poklonio O. Mateju dosta prostrano imanje na Glavotoku sa crkvicom sv. Marije, koja je dotada bila domaća kapela frankopanske obitelji“ (IVANČIĆ 1910: 30).

35 IVANČIĆ 1910: 32.

36 RUNJE 2012: 53.
} 
u Hrvatskoj. Naime, na lijevoj je strani škrinje prikazan samostan s trojicom redovnika zauzetih iskapanjem skrivenoga svečeva tijela, relikvije sv. Šimuna. ${ }^{37}$ Izgled njihova odijela jasno otkriva da je riječ o franjevcima trećorecima, o čemu je zapisao podatak i fra Stjepan Ivančić: „Da su Remete od pokore, dosliedno Redovnici III. reda bili koji su na stan primili mletačkog plemića i iznašli sveto Šimunovo tielo, to je bilo do najnovije dobe mnienje svih zadrana koji su dosad pisali što o ovom predmetu; a i predaja zadrana od punih šest viekova podudara se s ovim mnienjem". ${ }^{38}$

Vratimo se zaslugama franjevaca trećoredaca glagoljaša za očuvanje jezika. Navest ćemo jedan zanimljiv detalj tomu u prilog. Naime, obavljanje bogoslužja na staroslavenskome i upotreba hrvatskoga jezika u propovijedanju Božje riječi, ispovijedanju, dušobrižništvu, poučavanju mladeži i u ostalim potrebama, što nalazimo u pismu fra Antuna Juranića iz 1767., trećorecima je služilo kao argument prema mletačkoj Vladi, koja je gasila tzv. „nefunkcionalne“ samostane diljem Republike. Ovo i na ostale načine izraženo fra Antunovo zalaganje urodilo je plodom. Vlada ne samo da nije dotaknula ni jedan od 14 samostana franjevaca trećoredaca glagoljaša, nego im je mletački dužd Pavao Renier naredbom od 28. travnja 1783. darovao samostan otaca konventualaca u Krku za naobrazbu hrvatske mladeži krčkoga otoka, pri čemu će im kao sredstvo za postizanje toga cilja poslužiti upotreba staroslavenskoga jezika. ${ }^{39}$

Franjevci trećoreci njegovali su svoju glagoljašku tradiciju i budno su bdjeli nad njom, nad tom svojom ,svetinjom“ ${ }^{40}$ Nisu dopuštali da se na latinskom jeziku obavlja služba Božja, pa makar ikoji među njima završio studij u Italiji ili bio „vješt koliko mu drago latinštini. (...) Dapače služiti ju i latinski bez prave potrebe, smatrali su prestupkom, koji se imao strogo od Starješina kazniti““. ${ }^{41}$ Isto tako, nije se mogao zarediti, odnosno ostati u Dalmatinsko-istarskoj provinciji onaj tko ne bi znao „oficijati harvatski“ i „štiti pristojno harvatski““. ${ }^{42}$ Stoga je i veleučeni fra Ivan Sansoni, Rimljanin, poznat po svojim izvrsnim korizmenim propovijedima

37 Isto: $51 .$, ,Sva tri redovnika imaju na glavama velike tonzure, znak njihova svećeničko-redovničkoga statusa. Redovnik na lijevoj strani prikazan je kako se saginje u kopanju, s lopatom u pokretu nad glavom. Budući da je prikazano kopanje u tijeku, podignuta redovnikova ruka pokriva dio njegova lica - nos, oči i dio čela. Na njemu se vidi habit s pojasom i malo je nagnut, tako da mu je desna noga gola do koljena, a lijeva pokrivena habitom do potkoljenice. (...) $\mathrm{Na}$ čitavu habitu nema znakova krojačkoga zahvata, tako da on izgleda kao vreća s pričvršćenom kukuljicom, s kojom tvori jedinstveno odijelo (...)“.

Usp. Isto: 154.

Usp. Isto: 122.

$\mathrm{Na}$ istome mjestu.

Na istome mjestu. Taj se navod odnosio na fra Antuna Kavranića, koji je bio pripadnik Asiške provincije. 
u Šibeniku i Zadru, s velikim naporom morao, ,učiti hrvatski-glagolski jezik, da je u malo vremena mogao propoviedati u Prvić-Luci i glagolski pjevati sv. Misu“ ${ }^{43}$

Već smo spomenuli da su se trećoreci glagoljicom i narodnim jezikom služili i u svojim izvanliturgijskim potrebama: pisanim poslanicama poglavara, privatnim i javnim pismima, samostanskim knjigama, zapisnicima, dnevnicima, imovnicima i sl. Prilikom službenoga posjeta, vizitacije, talijanski su poglavari vizitatori redovito sa sobom vodili i tajnike koji bi poznavali glagoljicu i narodni jezik, a njihova su se izvješća na kraju vizitacije prevodila na hrvatski i zapisivala glagoljicom. ${ }^{44}$ Vizitator o. Feliks Josip Cornoldi predložio je 1747. da se Pravilo tiska na hrvatski jezik, što je 12 godina kasnije ostvario fra Antun Juranić, pod naslovom Regula tretoga Reda Sv. O. Frančiska za provinciu od Dalmacie na slavu Isusa, Marie, Sv. O. Fran. preneseno iz talianskoga na jezik Slovinski po M. P. F. Antonu Juranichu pridajuchi nike molitve etc. U Rimu po Antonu Fulgoni 1788. ${ }^{45}$

Fra Stjepan Ivančić u svojim je Povjestnim crtama zabilježio i „Razne pohvalnice u prilog porabi glagolice“. I njemu su bile najzanimljivije pohvalnice koje su zapisali stranci jer oni ,niesu mogli iz prirodjenog čustva biti zanešeni za glagolicom“" ${ }^{46}$ Tako 1781. opunomoćenici grada Zadra (i procuratori presidenti della spettabile università dei cittadini e popolo della città di Zara) pismom za franjevce trećorece glagoljaše izjavljuju: ,točni u pobožnoj službi staroslavenskim jezikom (...) buduć jedini izmedju redovnika, koji su od njihova postanka rabili i sačuvali do sada staroslovenski jezik u bogoslužju na duhovni probitak puka i naroda “" ${ }^{47}$ Iste godine vijećnici i podestat Zadra (i consiglieri e capo della magnifica comunità di Zara) također pišu: ,nije im samo u osobitu zaslugu što su oni prvi primili velike moći slavnoga tiela sv. Šimuna proroka (...) što su koristno i zaslužno dvorili okuženike u strašnim nezgodam, nego od njihova postanka jedini su izmedju redovnika, koji i dandanas čitaju i pjevaju mise i obavljaju bogoslužje u koru staroslavenskim jezikom (...) uzgajaju hrvatsku mladež i nju podučavaju u vjerskim i književnim stvarima“".48

Ovdje ćemo spomenuti i komentare fra Stjepana Ivančića, vezane uz pojavu protestantizma, kada je izgledalo da će protestanti iskoristiti glagoljicu i staroslavenski jezik u bogoslužju za širenje svojega nauka među Slavenima. U tome nisu uspjeli jer se ondje gdje je bila glagoljica i gdje je po crkvama u bogoslužju odzvanjao hrvatski jezik protestantizam nije mogao ukorijeniti. „U

\footnotetext{
$\overline{43}$ Isto: 123 . Uz njega se ovdje spominje i njegov učenik o. Ivan Štilac Secco, Španjolac, koji je tako dobro govorio hrvatski kao da je rođeni Hrvat.

44 Usp. IVANČIĆ 1910: 147.

45 Isto: 143.

46 Isto: 147.

47 Isto: 148.

$48 \mathrm{Na}$ istome mjestu.
} 
same četiri godine 1560-64 dadoše Protestanti u Norimbergi i u Tubingi tiskati do 14 glagolski napisanih knjiga, da tobož ponarodjenim crkvenim jezikom privabe k sebi hrvatski dotično slovenski narod. Al u Dalmaciji, Istri, i u obće po svim hrvatskim zemljama bila im loša sreća; jer uprav glagolica, kojom su kanili postići naumljeni cilj, pomrsi im račune“" ${ }^{49}$ Stoga Ivančić ima zanimljiv i zanosan prijedlog. Budući da se Hrvatska u borbi protiv Turaka nazivala antemurale christianitatis, tako bi se u obrani protiv protestantizma trebala nazvati antemurale catholicitatis. ${ }^{50}$

Nakon svega navedenog postaje jasno kako je nužno promijeniti krivo mišljenje o srednjovjekovnim hrvatskim trećorecima kao o zaostalima i neukima. Prema broju crkvenih knjiga kojima su se služili i koje su bile njihovo vlasništvo, prema stručno učinjenim prijevodima Sv. pisma i crkvenih otaca, kao i prema materijalnom blagostanju, bili su ,na vrhuncu ljestvice dobrostojećih kulturnih radnika“ . ${ }^{51}$ Osim hrvatskoga, talijanskoga i, razumljivo, staroslavenskoga jezika, poznavali su i latinski i grčki, što se može dokazati preciznošću i stručnošću u glagoljskim tekstovima. ${ }^{52}$

Franjevci trećoreci glagoljaši bili su duboko svjesni povlastice koju je uživao hrvatski narod: da može slaviti Boga u svetoj liturgiji na jeziku bliskom narodnomu. Stoga su se međusobno poticali na učenje jezika, kako bi bili što pristupačniji puku, kako bi njihove propovijedi rasvijetlile um, dirnule srce, ganule volju. Jer, ukoliko puk bude razumio njihove nagovore i propovijedi, savjete i usmjerenja prilikom dijeljenja sakramenta sv. ispovijedi, tada će porasti čestitost, poštenje i pobožnost, a s time će doći i sva ostala dobra hrvatskomu narodu.

Franjevci trećoreci glagoljaši ostavili su duboke tragove u živoj vjeri, kršćanskomu svjetonazoru i kulturi hrvatskoga naroda iz kojega su potjecali, što je nesumnjivo velik kulturni prinos zapadnoj civilizaciji. Ujedno je to i poticaj na daljnje njegovanje, učenje i čuvanje te naše „svetinje“ jezika hrvatskoga. Ako su se franjevci trećoreci glagoljaši u stara vremena, kada nisu imali suvremena tehnička i digitalna pomagala, kada je za jedan misal zapisan na pergameni trebalo žrtvovati pravo materijalno bogatstvo, mogli očuvati glagoljašku tradiciju, neka na nama ostane barem toliko da, upoznati s tim njihovim zaslugama, znamo to cijeniti i prenositi budućim naraštajima. Neka nam kao poticaj za njegovanje i čistoću hrvatskoga jezika bude njihova revnost i briga za glagoljicu i narodni jezik.

\footnotetext{
49 Isto: 137.

$50 \mathrm{Na}$ istome mjestu.

51 RUNJE 1990: 52.

52 Usp. Isto: 115.
} 


\section{Zaslužni franjevci trećoreci glagoljaši u mogućem nastavnom programu hrvatskoga jezika i književnosti}

Od osoba zaslužnih za njegovanje i očuvanje glagoljaške tradicije koji su obogatili hrvatsku kulturu i povijest, ovdje ćemo istaknuti četvoricu, a to su: fra Matej Bošnjak Mastilić, fra Stjepan Belić, fra Šimun Klimantović i fra Stjepan Ivančić.

1. Fra Matej (Bošnjak) Mastilić (o. 1420. - 1525.)

O fra Mateju, po mnogočemu zaslužnom franjevcu trećorecu, njegov subrat fra Stjepan Ivančić navodi sljedeće: „Rodio se u Bosni negdje oko god. 1420. kad su, rekao bih, najviše po toj pokrajini Turci harali. Kad mu je bilo 25 godina, zarobili Turci svukoliku njegovu obitelj, te poveli u Tursku otca mu, majku, nekoliko braće i sestara, dočim se je on, momak pun snage, nekako oslobodio iz njihovih ruku i sretno pobjegao u Dalmaciju. Prispjev u Zadar, kao što on sam kaže, Bogom nadahnut obuče haljine trećega samostanskog Reda Sv. Franje, te stade svim marom revnovati za njegovu moralnu i materijalnu probit" ${ }^{53}$ Ta je njegova revnost za moralnu i materijalnu dobrobit u njegovoj zajednici bila prepoznata i priznata. Budući da je postigao to da je papa Aleksandar VI. 24. srpnja 1499. udijelio punu samostalnost franjevcima trećorecima u Dalmaciji i Istri, što je značilo da imaju potpunu neovisnost o Prvome franjevačkom redu, na kapitulu je 1502. dobio priznanje od svoje redovničke zajednice, ali i atribut „obnovitelj ili uskrsitelj zajednice“ ${ }^{\text {“54 }}$, što dovoljno govori o njegovoj važnosti za zajednicu i o njezinoj zahvalnosti.

Neki mu pripisuju da je sudjelovao pri izdavanju hrvatskoga prvotiska, Misala po zakonu rimskoga dvora iz 1483. Ipak, sigurno je da je 16. srpnja 1492. u mletačkoga tiskara Pelegrina de Pasqualibusa Bononiensisa tiskao inkunabulu pod naslovom Ispovidi, od koje se do danas nije očuvao nijedan primjerak. Posrijedi je knjižica sadržajno dvostruke funkcije, kao svećenički priručnik za sakrament svete ispovijedi te vjernički molitvenik kod sakramenta ispovijedi. U pravom je smislu bila trećoredska po naglašenoj pastoralnoj skrbi za vjernika i po preporuci da ju je „vsaki krstjanin držan imiti i umiti i naučiti“ ${ }^{55}$ Tekst joj je sastavljen na hrvatskom jeziku, a moguće je da je tiskana i na hrvatskoj ćirilici (bosančici) ${ }^{56}$ Dokaz o njezinu tiskanju nalazi se u Tkonskom zborniku, gdje piše: „V ime Božie i s(ve)te Marie amen. svršenie Ispovidi ku e vsaki krstjanin držan imiti i umiti i naučiti i bi svršenie ne na let g(ospo)dnih 1492 miseca ijuleê na dan 16. i bi uči-

\footnotetext{
IVANČIĆ 1910: 163.

RUNJE 2012: 154.

55 Usp. Isto: 157.

$56 \mathrm{Na}$ istome mjestu.
} 
nena ta štampa na počtu počtovanoga g(ospo)d(i)na Žuvana Grimalarke i negova sinovca $g(o s p o) d(i) n a$ Êndriê i bi učinena ta štampa u kući mešta Pelegrina iz Bologne a bih ê fra Matii Zadranin on ki ju složih zato vi ki ju budete te (!) čtati blagoslovite a ne klnite zač ju ni složila ruka anjelska nego človeka grišnika zato vi napravite vašim razumom" ".57

Fra Stjepan Ivančić zapisat će za fra Matiju (Bošnjaka) Mastilića kako „on zaslužuje da se njegovo ime zlatnim slovima zabilježi u našoj povjestnici“ te ga punim pravom možemo nazvati ,prvim Otcem i Osnovateljem Dalmatinske trećoredske Redodržave“. ${ }^{58}$ Trećorecima glagoljašima ostavljamo zadatak da se pobrinu za zlato i zlatna slova svojemu subratu, a današnjim sastavljačima čitanki i udžbenika da u svojim priručnicima posvete jednu rečenicu ovomu zaslužnom redovniku glagoljašu.

2. Fra Stjepan Ivančić (Cres, 1852. - Zadar, 8. IV. 1925.)

Jednu od najsnažnijih potvrda glagoljaštva u franjevaca trećoredaca predstavlja rukopisni kodeks Ivančićev glagoljski kodeks ili Ivančićev zbornik, nastao u drugoj polovini 14. stoljeća. ${ }^{59}$ Nazvan je po fra Stjepanu Ivančiću († 1925.), koji ga je 1880-ih prvi opisao, obradio osnovne jezične značajke, prikazao sadržaj i objavio neke njegove tekstove te tako predao taj glagoljski kodeks znanstvenoj javnosti. Do Prvoga svjetskog rata franjevci trećoreci glagoljaši čuvali su ga u samostanu sv. Marije na Glavotoku, a danas se nalazi u Provincijskom arhivu franjevaca trećoredaca na Ksaveru u Zagrebu.

U Ivančićevu zborniku nalazi se prijevod Pisma vjernicima I. sv. Franje. Od svih pisama koje je sv. Franjo napisao, do danas ih je očuvano desetak. Dva su pisma upućena svim vjernicima, od kojih se Pismo vjernicima I. tek posljednjih petnaestak godina uvrštava među autentične spise sv. Franje. Imamo ga u jednom jedinom latinskomu srednjovjekovnom kodeksu iz grada Volterre ${ }^{60}$ te u Ivančićevu zborniku, gdje je dio teksta (14 rečenica prvoga dijela) pisan glagoljicom u hrvatskom prijevodu. Počinje prijevodom latinskoga teksta: „Hec sunt verba vite et salutis que si quis legerit et fecerit inveniet vitam et hauriet salutem a Domino“, koji na (staro)hrvatskom glasi: „,SE SUT’ RIČI ŽIVOTA I SPASENIÊ AKO GDO ČTITI BUDE I ČINITI NAIDET ŽIVOT VÊČNI I POČR'PET' SPASENIE OT GOSPODA“. Budući da je naslov pisma sv. Franje upućen „onima koji čine pokoru“, iz toga jasno proizlazi da „Franjo nije želio ustrojstvo, organizaciju, 'ordo'“. On je želio evanđelje s naglaskom na 'obratite se', 'metanoja', što je

\footnotetext{
Isto: 161.

58 IVANČIĆ 1910: 40.

59 Usp. RUNJE 1990: 18.

60 Objavio ga je 1900. Paul Sabatier, pronašavši tekst pisma u Il codice 225 della Biblioteca Guarnacci di Volterra (RUNJE 2012: 25).
} 
'plod dostojan pokore' ${ }^{61}$ Stoga fra Petar Runje predlaže da „,budući naziv 'Pisma vjernicima I.' u 'Spisima sv. Franje' bude 'Pismo pokornicima'“. ${ }^{62}$

Osim navedenoga glagoljskog kodeksa, fra Stjepanu Ivančiću dugujemo veliku zahvalnost za njegov doprinos proučavanju povijesti franjevaca trećoredaca glagoljaša, kao i za objavljen tekst o ,porabi glagoljice“" među franjevcima trećorecima glagoljašima. Za zahvalnost na prvom doprinosu neka se pobrinu njegova subraća, a za tekst o upotrebi glagoljice svi mu dugujemo jedan spomen, jednu rečenicu njemu posvećenu u budućim nastavnim priručnicima.

3. Fra Šimun Klimantović (Lukoran na Ugljanu, o. 1460. - 1520.)

O fra Šimunu znamo da je suvremenik fra Stjepana Belića. Rođen je u Lukoranu na Ugljanu oko 1460. Kao marljivom i učenom redovniku, zajednica mu je povjeravala različite odgovorne službe. Iako nemamo puno biografskih podataka o njemu, znamo da je bio čovjek vedre naravi, koji je teškoće života prihvaćao u duhu franjevačke jednostavnosti. Znao se na svoj račun i na račun siromaštva u zajednici i našaliti, što je na jednom Obredniku kao bilješku i zapisao: „I tada ne imihomo v' našem' molstiri rečenom ni žita ni muke ni vina ulie kaplice, a krušca vele pomalahno. A fr. Matii Ručica ${ }^{63}$ posla me na Komrčar' negovu gusternu piti vodu ž' nee od glada ne mogoh' ju prepiti, ošće e nemu ostavih' delak““ ${ }^{64}$ Jasno da se ovdje našalio i na račun fra Mateja (Bošnjaka) Mastilića, koji je bio „poznat i hvaljen zbog neobične sposobnosti za izgradnju tako potrebnih gusterna u priobalnom dijelu Damlacije“ ${ }^{65}$ Godine 1505. fra Šimun opet je na Zaglavu i na istom Obredniku zapisuje tekst koji govori o gladi u Zadru, tumačeći tu glad kao kaznu za grijehe, te dodaje: „A to zapisah' ê fra Šimun Klimantović' tretoga reda, komu je zemla mati, črvi druzi, grob otoč'stvo' grisi bogatstvo. Bože smilui se na mene grišnika i na sve hrstiêne. Amen. I tada činiahu kruh v' Zadri od boba, i ne biše ga“" ${ }^{66}$

Iako su nam zanimljivi i ovi navedeni podaci iz njegova života, sada i ovdje zanimaju nas njegovi glagoljski kodeksi, koji su se pisali i prepisivali u Komrčaru na Rabu početkom 16. stoljeća, budući da se fra Šimun stručno bavio prepisivanjem i ukrašavanjem knjiga. Od očuvanih rukopisnih glagoljskih kodeksa, napisao je najmanje četiri.

Jedan je od najvažnijih datuma u franjevaca trećoredaca glagoljaša 12. travnja 1492., kada je na otočiću Galevcu (Školjiću) nasuprot Zadra održan Kapitul „,bra-

\footnotetext{
RUNJE 2012: 31.

62 Na istome mjestu.

63 Matej (Bošnjak) Mastilić imao je nadimak Ručica.

64 RUNJE 2012: 195.

65 Isti 1990: 177.

66 IVANČIĆ 1910: 225, Prilog D.
} 
tie pokornih tretoga reda blaženoga Frančiška provencie Dalmacie“ “. ${ }^{67}$ Bio je to izvanredan kapitul, sazvan nakon 1480., kada je zajednica franjevaca trećoredaca izgubila neovisnost i bila pravno podložna franjevcima Prvoga reda. Na rečenom su Kapitulu franjevci trećoreci, svjesni gubitka samostalnosti, koju su se trudili obnoviti, donijeli odredbe o načinu života te kazne prekršiteljima tih odredbi, nazvane Konstitucije. Odredbe su se odnosile na sve članove Provincije, a ne samo na školjićku zajednicu. Uz detaljno navedene kazne prekršiteljima zakona (uskraćivanje hrane, zatvor, bičevanje i sl.), Konstitucije otkrivaju i strog život u redovničkoj zajednici (obveza svakodnevnoga moljenja časoslova, svakodnevnoga prisustvovanja sv. misi, sv. ispovijedi svakih petnaest dana, trajnoga nošenja redovničkoga odijela, zabrana upotrebe plahte, osim u bolesti, obdržavanje šutnje u kući, kao i za vrijeme obroka, izlazak iz samostana samo uz dopuštenje poglavara i sl.). ${ }^{68}$ Pisane su glagoljicom na onodobnom hrvatskomu jeziku ${ }^{69}$ te predstavljaju „važan spomenik hrvatskoga književnog jezika (čakavskog) s konca 15. stoljeća“. ${ }^{70}$ Početak trećoredskih Konstitucija, zapisanih fra Šimunovom rukom, ide ovako: „Ovo jesu koštitucijoni bratje pokornih III. Reda bl. Frančiška, provencije Dalmacije, učinjene oda sve bratje na kapituli na Školji Galevci prid Zadrom na let Božjih 1492, na 12 dan miseca aprila“" ${ }^{71}$ Konstitucije su očuvane u nekoliko istovjetnih prijepisa sa samoga početka 16. stoljeća. Budući da su zapisane u kodeksima fra Šimuna Klimantovića, u stručnoj literaturi i u krugu redovničke zajednice franjevaca trećoredaca glagoljaša nazivaju se Klimantovićeve konstitucije.

Iako se fra Šimun oslovljava kao „škritur“ te iako će sam za sebe zapisati da je „ni pisac ni pod piscem pisac" ${ }^{\text {“72, }}$, zasigurno je bio više od običnog prepisivača. Bio je plodan i vrstan prepisivač, dobar prevoditelj, a njegov doprinos očuvanju hrvatskoga jezika onoga doba dovoljan je razlog da njegovo ime i djela uđu u čitanke budućih srednjoškolaca.

4. Fra Stjepan Belić (Rab, oko 1460. - Ancona, 1523.)

Prvi poznati službeni učitelj glagoljice i staroslavenskoga u hrvatskoj književnoj i jezičnoj povijesti bio je trećoredac fra Stjepan Belić. Bio je profesor teologije i prava s tadašnjim akademskim naslovom „doctor artium“. Učiteljsko mu je odobrenje i to u Kopru 23. travnja 1494. dodijelio fra Gabrijel, ministar Svete Zemlje

67 RUNJE 2012: 159.

Usp. Isti 2001: 175-176.

Primjerice, kapitul 38., zadnji, glasi: „Ki bi govoril' za stolom' bez prošteniê, kada se obedva al vičera, tomu pokora: Nedaite mu vino piti on' dan' za onim ' idêniem'“ (vidi IVANČIĆ 1910: 220, Prilog D).

70

RUNJE 1990: 22.

IVANČIĆ 1910: 130.

72 RUNJE 2003: 95. 
i povjerenik franjevačkoga generala za provinciju Istru, Dalmaciju i Albaniju, „zbog čestitog života i dobrog poznavanja staroslavenskoga jezika, u kojem svaki dan služi i obavlja svete obrede, javno naučavati i predavati staroslavenski jezik u školama u svim gradovima i mjestima“". ${ }^{73}$

Ovo službeno imenovanje potvrđuje još nešto. Naime, ako je službeno imenovan učiteljem glagoljice i staroslavenskoga jezika, onda su morale postojati i škole na kojima je taj učitelj predavao i u kojima je to znanje stekao, bilo one koje su onodobni trećoreci imali u svojim samostanima, bilo one javne ili gradske škole u kojima se stručno poučavao hrvatski jezik. S obzirom na preciznost i točnost norme u glagoljskim kodeksima, staroslavenskim knjigama i prijevodima, posebice u liturgijskim knjigama, morali su postojati dobri učitelji koji su poučavali, njegovali i čuvali jasnoću i čistoću norme. Stoga svim nasljednicima fra Stjepana Belića u čast, a budućim učiteljima hrvatskoga jezika u njihovu poučavanju velik poticaj neka bude ovaj, do sada prvi poznat službeni učitelj norme. A da bi on to i bio, njegovo se ime i njegova časna služba moraju uvrstiti u nastavne normativne priručnike hrvatskoga jezika.

\section{Zaključak}

Zajedno s dobrim poznavateljem trećoredske glagoljaške tradicije, fra Petrom Runjem, možemo zaključiti: „Hrvatski popovi glagoljaši izdanak su na stablu crkvenoslavenske ćirilometodijevske baštine, stručno osposobljeni u ozračju zapadne sredine, aktivni su stvaraoci visoke kulture hrvatskoga srednjovjekovlja“.

Tu glagoljašku tradiciju franjevci trećoreci glagoljaši ne prestaju njegovati. $U$ 40. članku njihovih Statuta stoji: „U specifičan apostolat naše Provincije spada i njegovanje naše glagoljaške tradicije kojom se i danas može nadahnjivati naša evangelizacija i ostali oblici našeg apostolata“. Tomu svakako pridonosi i Odjel za hrvatski glagolizam, koji je u sastavu Instituta za ekumensku teologiju i dija$\log$,Juraj Križanić“ Katoličkoga bogoslovnog fakulteta Sveučilišta u Zagrebu, a kojemu je pročelnik trećoredac fra Petar Bašić.

Uz navedeno dodajmo i ne manje važno da je na Kapitulu Franjevaca trećoredaca glagoljaša, održanom u Zagrebu od 2. do 5. travnja 2013., odlučeno da se u njihovu samostanu u Krku otvori Muzej trećoredske glagoljaške baštine. ${ }^{74}$ Smijemo se radovati toj njihovoj odluci i svesrdno je podržati. Otvorenje Muzeja trećoredske glagoljaške baštine, uz materijalno, kulturno i duhovno, poprima i dodatno značenje u očuvanju hrvatskoga identiteta, naročito ulaskom Hrvatske u zajednicu europskih naroda.

\footnotetext{
73 Isti 2001: 133 .

74 Vjesnik franjevaca trećoredaca 50 [2013]/1: 14.
} 


\section{Bibliografija}

ČAJKOVAC, Sigismund (prir.). 1940. Čitanka za IV. razred pučkih škola u Banovini Hrvatskoj. Surađivali Vladimir Nazor, Stjepan Bosanac, Stjepan Ratković. Zagreb: Izdanje naklade školskih knjiga i tiskanica Banovine Hrvatske.

Četvrta čitanka za pučke učione: sa zemljovidom Europe. 1879. Beč: U Ces. kr. nakladi školskih knjigah kod Sv. Anne.

Čitanka za drugi razred glavnih i gradjanskih školah. 1846. Trst: I. Papš, vladateljni slovotištitelj.

Čitanka za niže pučke škole u gradovima (trgovištima): Srednji stupanj (III. godište). 1906. Zagreb: Nakladom Kr. hrv.-slav.-dalm. zemaljske vlade.

Čitanka za treći razred obćih pučkih škola. 1889. Zagreb: Nakladom Kr. hrv.-slav.-dalm. zemaljske vlade.

DIVKOVIĆ, Mirko (prir.). 1889. Hrvatska čitanka za III. razred gimnazijski. Po izdanju prof. T. Smičiklasa preradio Mirko Divković, ravnatelj gimnazije zagrebačke. Zagreb: Troškom i nakladom Kr. hrv.-slav.-dalm. zem. vlade.

HORVATEK MODRIĆ I DR. 2011. Davorka Horvatek Modrić, Ruža Križan-Sirovica, Sanja Šepac Dužević, Marija Ćurić, Žarko Gazzari. Čitanka 1: čitanka za prvi razred četverogodišnje srednje strukovne škole. 2011. Zagreb: Školska knjiga.

IVANČIĆ, Stjepan. 1910. Povjestne crte o samostanskom III Redu sv. O. Franje po Dalmaciji, Kvarneru i Istri i poraba glagoljice u istoj redodržavi. Sa prilozima. Zadar: Tiskarna E. Vitaliani.

MILER, Ferdo Ž. 1891. Čitanka za seoske opetovnice. Naredbom visoke Kr. zem. vlade, Odjela za bogošt. i nast. od 22. rujna 1891. broj 10.413 obligatno uvedena u seoske opetovnice. Zagreb: Komis. naklada knjižare L. Hartmana (Stjep. Kugli).

MILER, Ferdo Ž. (prir.). 1898. Franje Petračića Hrvatska čitanka za više razrede srednjih škola. Knjiga druga: Povijest književnosti u primjerima. Treće izdanje. Zagreb: Troškom i nakladom Kr. hrv.-slav.-dalm. zem. vlade.

NIKOLIĆ, Ferdo. 1956. Pregled književnosti s primjerima: za VI. razred gimnazije. Zagreb: Školska knjiga.

NIKOLIĆ, Ferdo, Milena VEČERINA, Stanko DVORŽAK. 1955. Čitanka iz naše i strane književnosti za V. razred gimnazije. Zagreb: Školska knjiga.

PASARIĆ, Josip (prir.). 1925. Mirka Divkovića Hrvatska čitanka za III. razred srednjih škola. Deveto prerađeno izdanje. Zagreb: Izdanje, Naklada Društva hrvatskih srednjoškolskih profesora.

PASARIĆ, Josip, David BOGRANOVIĆ (prir.). 1924. Franje Petračića i Đure Zagode Hrvatska čitanka za više razrede srednjih škola. Dio prvi: Poetika, stilistika i proza. Zagreb: Izdanje, Naklada Društva hrvatskih srednjoškolskih profesora.

PETRAČIĆ, Franjo. 1880. Hrvatska čitanka za više gimnazije i nalike jim škole. Knjiga druga: Historija literature u primjerih. Zagreb: Troškom i nakladom Kr. hrvatskoslav.-dalm. zemaljske vlade.

ROSANDIĆ, Dragutin. 1997. Književnost 1. Udžbenik za 1. razred ekonomskih škola. Zagreb: Školske novine. 
RUNJE, Petar. 1990. Prema izvorima. Zagreb: Provincijalat franjevaca trećoredaca.

RUNJE, Petar. 2001. Pokornički pokret i Franjevci trećoredci glagoljaši (13.-16. st.). Zagreb: Provincijalat franjevaca trećoredaca, Kršćanska sadašnjost.

RUNJE, Petar. 2003. Školovanje glagoljaša. Ogulin: Matica hrvatska.

RUNJE, Petar. 2012. Prema izvorima II. Rasprave i članci o hrvatskim franjevcima trećoredcima glagoljašima. Ur. Tomislav Galović [Novaja i vethaja 9; Krčki zbornik 68, Posebno izdanje 61]. Krk-Zagreb: Povijesno društvo otoka Krka, Provincijalat franjevaca trećoredaca glagoljaša.

SMIČIKLAS, Tade. 1880. Hrvatska čitanka za III. razred gimnazijski. Zagreb: Troškom i nakladom Kr. hrv.-slav.-dalm. zem. vlade.

ŠPANJIĆ, Tanja, Dragica DUJMOVIĆ-MARKUSI. 2009. Čitanka 1: udžbenik hrvatskoga jezika za prvi razred trogodišnjih strukovnih škola. Zagreb: Profil.

ŠURMIN, Đuro, Stjepan BOSANAC. 1923. Čitanka iz književnih starina staroslovenskih, hrvatskih $i$ srpskih za VII. $i$ VIII. razred srednjih škola. Peto izdanje. Zagreb: Bibliografski zavod d. d., Nakladna knjižara.

TROGRLIĆ, Stipan. 2012. Istarsko hrvatsko svećenstvo i diplomatsko-politička borba za sjedinjenje Istre s Hrvatskom (1945.-1954.). Društvena istraživanja 21/2: 485-504.

ZRINJAN, Snježana, Snježana ZBUKOVIĆ-OŽBOLT. 2009. Čitanka za prvi razred trogodišnje strukovne škole. Zagreb: Školska knjiga.

ŽAGAR, Mateo. 2009. Glagoljica u hrvatskoj srednjovjekovnoj kulturi. U Povijest hrvatskogajezika. 1. knjiga: srednji vijek, ur. Stjepan Damjanović, 146-187. Zagreb: Croatica. 


\section{Presence of Tertiary Glagolitic Tradition in Croatian Language Teaching}

The paper presents the results of an examination of the presence of the tertiary Glagolitic tradition in the $19^{\text {th }}$ and $20^{\text {th }}$ century teaching books, in literary readers and language textbooks, to be more precise. The Glagolitic tertiaries have made great contribution to the Croatian science and culture and thereby deserved that the term "tertiary Glagolitic tradition" should be taken into teaching manuals. As a proof of that, names and works of the more significant Franciscan Glagolitic tertiaries will be stated here. Since the Glagolitic writing has been the unbroken tradition of tertiary Franciscans since the $15^{\text {th }}$ century, the Franciscan Glagolitic tertiaries form an indispensable part of that tradition so that it proves almost impossible to speak of the Glagolitic tradition without mentioning the tertiary Glagolitic tradition.

Keywords: instructional manuals in Croatian language, normative manuals in Croatian language, Glagolitic, Glagolitic friars of the Third order regular, fra Matej Bošnjak Mastilić, fra Stjepan Belić, fra Šimun Klimantović, fra Stjepan Ivančić

Ključne riječi: nastavni priručnici hrvatskoga jezika, normativni priručnici hrvatskoga jezika, glagoljaštvo, franjevci trećoreci glagoljaši, fra Matej Bošnjak Mastilić, fra Stjepan Belić, fra Šimun Klimantović, fra Stjepan Ivančić

Marija Stela Filipović Isusovačka klasična gimnazija s pravom javnosti u Osijeku HR-31000 Osijek, Vatroslava Lisinskog 1 marijastela@gmail.com 


\section{FILOZOFSKI FAKULTET SVEUČILIŠTA U ZAGREBU \\ ZAVOD ZA HRVATSKU POVIJEST \\ INSTITUTE OF CROATIAN HISTORY \\ INSTITUT FÜR KROATISCHE GESCHICHTE}
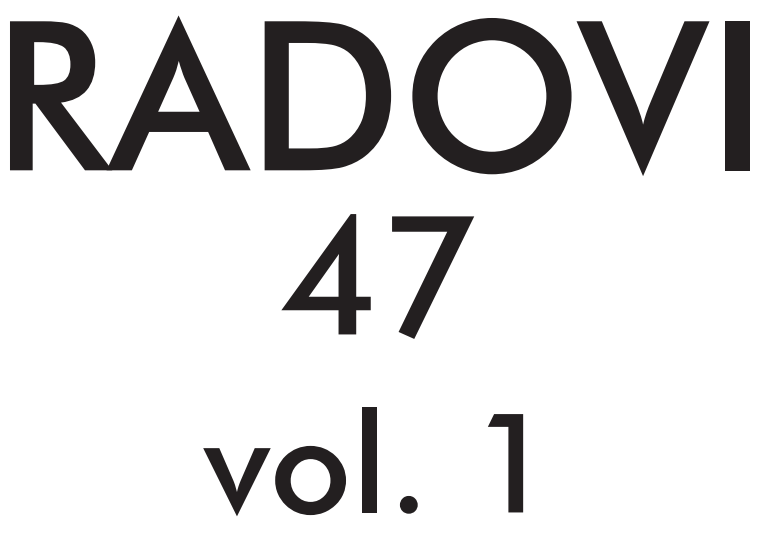

ZAVOD ZA HRVATSKU POVIJEST

FILOZOFSKOGA FAKULTETA SVEUČILIŠTA U ZAGREBU

\section{PF press \\ ZAGREB 2015.}




\title{
RADOVI ZAVODA ZA HRVATSKU POVIJEST FILOZOFSKOGA FAKULTETA SVEUČILIŠTA U ZAGREBU
}

\author{
Knjiga 47, vol. 1
}

\author{
Izdavač / Publisher \\ Zavod za hrvatsku povijest \\ Filozofskoga fakulteta Sveučilišta u Zagrebu \\ FF-press \\ Za izdavača / For Publisher \\ Vlatko Previšić \\ Glavni urednik / Editor-in-Chief \\ Hrvoje Gračanin \\ Izvršna urednica / Executive Editor \\ Inga Vilogorac Brčić \\ Uredništvo / Editorial Board
}

Bruna Kuntić-Makvić (stara povijest/ancient history), Zrinka Nikolić Jakus (srednji vijek/ medieval history), Hrvoje Petrić (rani novi vijek/early modern history), Željko Holjevac (moderna povijest/modern history), Tvrtko Jakovina (suvremena povijest/contemporary history),

Silvija Pisk (mikrohistorija i zavičajna povijest/microhistory and local history),

Zrinka Blažević (teorija i metodologija povijesti/theory and methodology of history)

Međunarodno uredničko vijeće / International Editorial Council

Denis Alimov (Sankt Peterburg), Živko Andrijašević (Nikšić), Csaba Békés (Budapest), Rajko Bratož (Ljubljana), Snježana Buzov (Columbus, Ohio), Svetlozar Eldarov (Sofija), Toni Filiposki (Skopje), Aleksandar Fotić (Beograd), Vladan Gavrilović (Novi Sad), Alojz Ivanišević (Wien),

Egidio Ivetić (Padova), Husnija Kamberović (Sarajevo), Karl Kaser (Graz),

Irina Ognyanova (Sofija), Géza Pálffy (Budapest), Ioan-Aurel Pop (Cluj),

Nade Proeva (Skopje), Alexios Savvides (Kalamata), Vlada Stanković (Beograd), Ludwig Steindorff (Kiel), Peter Štih (Ljubljana)

Izvršna urednica za tuzemnu i inozemnu razmjenu / Executive Editor for Publications Exchange Kristina Milković

Tajnik uredništva / Editorial Board Assistant

Dejan Zadro

Adresa uredništva/Editorial Board address

Zavod za hrvatsku povijest, Filozofski fakultet Zagreb, Ivana Lučića 3, HR-10 000, Zagreb

Tel. ++385 (0)1 6120 150, 6120 158, faks ++385 (0)1 6156879

Časopis izlazi jedanput godišnje / The Journal is published once a year

Časopis je u digitalnom obliku dostupan na / The Journal in digital form is accessible at Portal znanstvenih časopisa Republike Hrvatske „Hrčak“ http://hrcak.srce.hr/radovi-zhp

Financijska potpora za tisak časopisa / The Journal is published with the support by

Ministarstvo znanosti, obrazovanja i športa Republike Hrvatske

Časopis je indeksiran u sljedećim bazama / The Journal is indexed in the following databases:

Directory of Open Access Journals, EBSCO, SCOPUS, ERIH PLUS 
Naslovna stranica

Iva Mandić

Grafičko oblikovanje i računalni slog

Marko Maraković

Lektura

Samanta Paronić

Tisak

Web2tisak, Zagreb

Naklada

250 primjeraka

Časopis je u digitalnom obliku dostupan na Portalu znanstvenih časopisa Republike Hrvatske ,Hrčak“ http://hrcak.srce.hr/radovi-zhp

The Journal is accessible in digital form at the Hrcak - Portal of scientific journals of Croatia http://hrcak.srce.hr/radovi-zhp 


\section{RADOVI 47}

\section{vol. 1}

ZaVoda za hrVAtSku poviJest FILOZOFskoga fakulteta SVeuČILIŠTA u Zagrebu 


\title{
Tematski blok / Themed issue
}

\section{TREĆOREDSKA GLAGOLJAŠKA TRADICIJA U EUROPSKOM KONTEKSTU TERTIARY GLAGOLITIC TRADITION IN EUROPEAN CONTEXT}

\author{
Radovi međunarodnoga znanstvenog skupa \\ održanoga 27. i 28. IX. 2013. na Hrvatskom katoličkom sveučilištu u Zagrebu \\ u organizaciji \\ Provincije franjevaca trećoredaca glagoljaša u Zagrebu, Hrvatskoga katoličkog \\ sveučilišta u Zagrebu, Filozofskoga fakulteta Sveučilišta u Zagrebu - Odsjek za \\ povijest, Filozofskoga fakulteta Sveučilišta u Splitu - Odsjek za povijest, Instituta \\ za povijest umjetnosti u Zagrebu i Staroslavenskoga instituta u Zagrebu \\ Proceedings of the International Scientific Conference \\ held on 27th and 28th September 2013 at the Catholic University of Croatia in Zagreb \\ and organized by \\ the Province of the Glagolitic Friars of the Third Order Regular, Catholic University \\ of Croatia in Zagreb, Faculty of Humanities and Social Sciences of the University \\ of Zagreb - Department of History, Faculty of Humanities and Social Sciences of \\ the University of Split - Department of History, Institute of Art History, \\ and Old Church Slavonic Institute
}

Gosti urednici / Guest editors

\author{
Ivan BOTICA \\ Tomislav GALOVIĆ \\ Kristijan KUHAR
}

